\title{
Genotoxic potential of leaf extracts of Jatropha gossypiifolia L.
}

\author{
P.M. Almeida', ${ }^{1,2}$, S.S. Araújo1, I.R.M.R. Santos ${ }^{1}$, M.A. Marin-Morales ${ }^{3}$, \\ A.M. Benko-Iseppon ${ }^{1}$, A.V. Santos ${ }^{4}$, K.P. Randau ${ }^{4}$ and A.C. Brasileiro-Vidal' \\ 'Laboratório de Genética e Biotecnologia Vegetal, Departamento de Genética, \\ Universidade Federal de Pernambuco, Recife, PE, Brasil \\ 'Laboratório de Genética, Departamento de Saúde, Universidade Estadual do Piauí, \\ Teresina, PI, Brasil \\ ${ }^{3}$ Laboratório de Mutagênese, Departamento de Biologia, \\ Universidade Estadual Paulista Júlio de Mesquita Filho, Campus de Rio Claro, \\ Rio Claro, SP, Brasil \\ ${ }^{4}$ Laboratório de Farmacognosia, Departamento de Ciências Farmacêuticas, \\ Universidade Federal de Pernambuco, Recife, PE, Brasil \\ Corresponding author: A.C. Brasileiro-Vidal \\ E-mail: brasileirovidal.ac@gmail.com \\ Genet. Mol. Res. 15 (1): gmr.15017415 \\ Received August 11, 2015 \\ Accepted October 19, 2015 \\ Published February 5, 2016 \\ DOI http://dx.doi.org/10.4238/gmr.15017415
}

ABSTRACT. Jatropha gossypiifolia L. (Euphorbiaceae) is widely used in popular medicine. However, further toxicological studies are necessary for its reliable use. The present study aimed to evaluate the cytotoxic, genotoxic, and mutagenic effects of ethanolic and aqueous leaf extracts of J. gossypiifolia, using the test system Allium cepa. In addition, the phytochemical profile of the extracts was also obtained. Seeds of $A$. cepa were subjected to different concentrations of the two extracts $(0.001,0.01$, $0.1,1$, and $10 \mathrm{mg} / \mathrm{mL}$ ). Distilled water was used for the negative control and methyl methanesulfonate $\left(4 \times 10^{-4} \mathrm{M}\right)$ and trifluralin $(0.84 \mathrm{ppm})$ for the positive controls. The values of mitotic index at all concentrations of ethanolic extract and at $0.1,1$, and $10 \mathrm{mg} / \mathrm{mL}$ aqueous extract showed a significant decrease. Alterations, such as chromosome adherence, 
C-metaphases, chromosome bridges, nuclear buds, and micronuclei were verified in both extracts but chromosome loss indicating genotoxic activity was observed only in the ethanolic extract. Presence of micronuclei on administration of the extracts, also indicated mutagenic action at the chromosome level. In the ethanolic extract, aneugenicity seemed to be the main activity, probably as a result of the action of terpenes and/or flavonoids, whereas in the aqueous extract, clastogenic action appeared to be the principal activity, presumably as a consequence of the effect of flavonoids and/or saponins. Thus, we suggest that the extracts of this species should be used with great caution for medicinal purpose.

Key words: Chromosome alterations; Aqueous extract; Ethanolic extract; Phytochemical profile; Allium cepa test

\section{INTRODUCTION}

Jatropha gossypiifolia L. (Euphorbiaceae), also known as cotton-leaf physicnut, is a milky-bush used for medicinal purposes and is distributed around Latin America, the Caribbean, India, Western Africa, and Oceania (Kawanga, 2007). Its root, stem, and leaves possess cytotoxic, antitumor, antimalarial, antimicrobial, and insecticidal activities, among others (Devappa et al., 2011; Sabandar et al., 2013), whereas, its latex has bactericidal and cicatrizing effects (Oliveira et al., 2010). J. gossypiifolia leaves have been consumed in the form of tea (decoction or infusion) and are effective against general inflammation and eye pain, whereas the leaves in natura are used in the healing of wounds (Oliveira et al., 2010) and uterine colic (Paes et al., 2012). The phytochemical profile of the ethanolic extract of $J$. gossypiifolia has revealed the presence of steroids, phenols, tannins, saponins, oils, monoterpenes, diterpenes, triterpenes, and sesquiterpenes in the stem, leaves, and roots (Mariz et al., 2010; Devappa et al., 2011; Sabandar et al., 2013). However, phytochemical evaluations of aqueous extracts are still incipient, even though the plant is popularly used in the form of an infusion or decoction (Félix-Silva et al., 2014).

Despite the therapeutic advantages, the chemical substances present in the leaves of J. gossypiifolia could be toxic, as observed in house mice and fish (Singh and Singh, 2012), particularly due to the presence of diterpenes. Because the leaves of $\mathrm{J}$. gossypiifolia empirically used by the population contain chemical substances that could be harmful to health, more studies regarding their toxicological potential become necessary.

Due to its reliability and concordance with other genotoxicity assays, the test system Allium cepa is generally employed for the preliminary evaluation of genotoxicity of compounds for medicinal purposes (Bagatini et al., 2007). In this context, the present study was undertaken to examine the cytotoxic, genotoxic, and mutagenic effects of the ethanolic and aqueous leaf extracts of J. gossypiifolia, at the chromosome level, using the test system $A$. cepa, and relating the obtained results to the respective phytochemical profiles.

\section{MATERIAL AND METHODS}

\section{Biological material}

Leaves of J. gossypiifolia were collected from an adult plant in Teresina (Northeast, 
Brazil), in July 2012. Herbarium specimens containing leaves, flowers, and fruits were stored at the Herbarium Afrânio Fernandes at the State University of Piauí (UESPI, Teresina, Brazil; voucher specimen number: HAF 03111). Seeds of $A$. cepa cv. Vale Ouro IPA - 11 used in the bioassays were kindly provided by the Agronomic Institute of Pernambuco (IPA, Recife, Brazil). This paper describes experiments carried out under the standard procedures of scientific ethics.

\section{Preparation of leaf extracts}

Leaves of $\mathrm{J}$. gossypiifolia were placed in an incubator at $45^{\circ}-50^{\circ} \mathrm{C}$, for 5 days. The dry material was macerated in liquid nitrogen until a fine powder was obtained. The ethanolic extract (EE) was prepared by adding $1 \mathrm{~L}$ absolute ethylic alcohol to the leaf powder $(100 \mathrm{~g})$, and incubating at $300 \mathrm{rpm}$, for $24 \mathrm{~h}$. Subsequently, the extract was filtered and stored at $4^{\circ} \mathrm{C}$. The extract was rota-evaporated and diluted with distilled water, to obtain five concentrations $(0.001,0.01,0.1,1$, and $10 \mathrm{mg} / \mathrm{mL}$ ).

The aqueous extract $(\mathrm{AE})$ was obtained by infusion of the leaf powder $(100 \mathrm{~g})$ in $1 \mathrm{~L}$ distilled water for $10 \mathrm{~min}$, which was subsequently filtered and diluted with distilled water to the same concentrations, as EE. Both the extracts were used in the A. cepa assay.

\section{Allium cepa assay}

One hundred seeds of $A$. cepa were germinated on Petri dishes containing filter papers moistened with distilled water, at room temperature. After germination, the seeds were transferred to the five concentrations of the leaf extracts mentioned previously, with one dish for each concentration, for $24 \mathrm{~h}$. Distilled water was used as a negative control (NC), wheras $4 \mathrm{x}$ $10^{-4} \mathrm{M}$ methyl methanesulfonate having clastogenic and $0.84 \mathrm{ppm}$ trifluralin having aneugenic effect (Fernandes et al., 2009) were employed as positive controls. The root tips were fixed in ethanol:acetic acid solution $(3: 1)$ and stored at $-20^{\circ} \mathrm{C}$. The slides were prepared and stained with Schiff's reagent according to Fernandes et al. (2009).

Cytotoxicity (mitotic index - MI), genotoxicity (frequency of chromosome alterations - CA), and mutagenicity at the chromosome level (frequency of micronuclei - MN) were evaluated by scoring 5000 meristematic cells (500 cells/slide; 10 slides per treatment) under a light microscope. Alterations resulting from aneugenic (interference with the fibers of the mitotic spindle) and clastogenic effects (breaks in the genetic material) denoted genotoxicity.

The presence of MN was evaluated in $5000 \mathrm{~F}_{1}$ cells (originating from the mitotic division of meristematic cells; 500 cells/slide; 10 slides per treatment) to assess the persistence of mutagenicity of the leaf extracts at the chromosome level (Ma et al., 1995). For preparation of the slides with $\mathrm{F}_{1}$ cells, the roots were cut at a region $1 \mathrm{~mm}$ above the meristematic region. The meristematic and $\mathrm{F}_{1}$ cells were analyzed under a conventional microscope (DME, Leica Microsystems, Leica do Brasil Importação e Comércio Ltda., São Paulo, SP, Brazil) at 400X magnification.

\section{Phytochemical analysis of leaf extracts}

The phytochemical profile was determined by thin-layer chromatography. Different metabolites (triterpenes and steroids, monoterpenes, diterpenes and sesquiterpenes, alkaloids, coumarins, phenylpropanoid glycosides, flavonoids, cinammic derivatives, hydrolyzable tannins, condensed tannins, anthraquinones, and saponins) were tested according to Randau et al. (2004). 


\section{Statistical analysis}

The indices of cytotoxicity, genotoxicity, and mutagenicity were analyzed in a completely randomized experimental design. The data were evaluated by non-parametric test of Kruskal-Wallis, followed by a posteriori test of Student-Newman-Keuls $(P<0.05)$ using the BioEstat 5.3 program (Ayres et al., 2007). Only cytotoxicity data for both the extracts displayed normal distribution and homogeneity of variances, and were analyzed with the parametric test of Scott-Knott $(P<0.05)$ using the Assistat 7.7 program (Silva and Azevedo, 2002).

\section{RESULTS}

For cytotoxicity, the values of $\mathrm{MI}$ in meristematic cells at all concentrations of EE and at $0.1,1$, and $10 \mathrm{mg} / \mathrm{mL}$ of $A E$ presented statistically significant dose-dependent decrease (Figure 1).

Evaluation of CA revealed that the increase in all indices (Tables 1 and 2) was dosedependent and significant for the extracts when compared with the negative control, except for 0.001 and $0.01 \mathrm{mg} / \mathrm{mL}$ of $E E$ and $0.001 \mathrm{mg} / \mathrm{mL}$ of $A E$, indicating a genotoxic action of both the extracts.

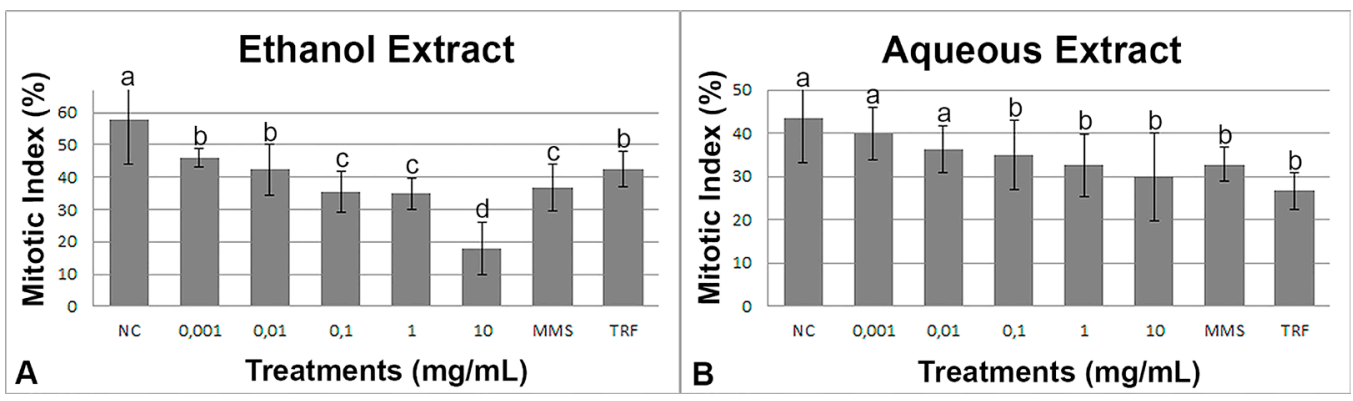

Figure 1. Mitotic index values for meristematic cells of Allium cepa, observed after 24-h exposure to ethanolic and aqueous extracts of Jatropha gossypiifolia at different concentrations (NC: negative control; MMS: methyl methanesulfonate, positive control; TRF: trifluralin, positive control). Scott-Knott test $(P<0.05$; averages followed by the same lowercase letter were not significantly different) results refer to analysis of 5000 cells per treatment.

Table 1. Frequency of chromosome alterations in meristematic cells and of micronuclei (MN) in $\mathrm{F}_{1}$ cells of $A$ llium cepa radicles after 24-h exposure to the ethanolic leaf extract of Jatropha gossypiifolia.

\begin{tabular}{|c|c|c|c|c|c|c|c|c|}
\hline \multirow{2}{*}{ Chromosome alteration } & \multicolumn{8}{|c|}{ Frequency $(\%)$} \\
\hline & Distilled water ${ }^{1}$ & 0.001 & 0.01 & 0.1 & 1 & 10 & $\operatorname{MMS}\left(4 \times 10^{-4} \mathrm{M}\right)$ & Trifluralin $(0.84 \mathrm{ppm})$ \\
\hline Chromosome adherence & $0.04 \pm 0.08$ & $0.36 \pm 0.33^{* *}$ & $0.07 \pm 0.16$ & $0.57 \pm 0.26^{\star \star}$ & $0.36 \pm 0.44^{*}$ & $0.24 \pm 0.32$ & $0.20 \pm 0.14$ & $0.59 \pm 0.12^{\star \star}$ \\
\hline C-metaphase & $0.04 \pm 0.08$ & $0.19 \pm 0.17$ & $0.05 \pm 0.09$ & $0.35 \pm 0.45$ & $1.24 \pm 0.90^{\star \star}$ & $0.07 \pm 0.12$ & $0.19 \pm 0.28$ & $0.38 \pm 0.12^{\star \star}$ \\
\hline Chromosome loss & $0.02 \pm 0.05$ & $0.19 \pm 0.24$ & $0.10 \pm 0.14$ & $0.03 \pm 0.07$ & $0.22 \pm 0.22^{\star \star}$ & $0.20 \pm 0.22^{*}$ & $0.19 \pm 0.16^{* \star}$ & $0.21 \pm 0.07^{\star \star}$ \\
\hline Binucleated cell & $0.00 \pm 0.00$ & $0.00 \pm 0.00$ & $0.00 \pm 0.00$ & $0.18 \pm 0.44$ & $0.04 \pm 0.13$ & $0.39 \pm 0.58$ & $0.00 \pm 0.00$ & $0.11 \pm 0.09$ \\
\hline Polyploid cell & $0.00 \pm 0.00$ & $0.00 \pm 0.00$ & $0.02 \pm 0.06$ & $0.06 \pm 0.13$ & $0.02 \pm 0.06$ & $0.02 \pm 0.06$ & $0.00 \pm 0.00$ & $0.21 \pm 0.09^{* \star}$ \\
\hline Multipolar anaphase & $0.00 \pm 0.00$ & $0.00 \pm 0.00$ & $0.00 \pm 0.00$ & $0.00 \pm 0.00$ & $0.04 \pm 0.07$ & $0.02 \pm 0.06$ & $0.00 \pm 0.00$ & $0.20 \pm 0.11^{\text {** }}$ \\
\hline Lobulated nucleus & $0.00 \pm 0.00$ & $0.00 \pm 0.00$ & $0.00 \pm 0.00$ & $0.00 \pm 0.00$ & $0.00 \pm 0.00$ & $0.30 \pm 0.53$ & $0.00 \pm 0.00$ & $0.28 \pm 0.10^{* \star}$ \\
\hline Nuclear bu & & $0.10 \pm 0$ & $0.39 \pm 0.49$ & $0.24 \pm 0.24$ & $0.55 \pm 0.55^{*}$ & $1.28 \pm 0.68^{* *}$ & $0.26 \pm 0.35$ & $0.31 \pm 0.28$ \\
\hline Micronuclei & $0.04 \pm 0.08$ & $0.45 \pm 0.35^{\star^{2}}$ & $0.40 \pm 0.40$ & $0.51 \pm 0.31^{*}$ & $0.80 \pm 0.77^{\star \star}$ & $4.11 \pm 3.69^{* *}$ & $1.69 \pm 0.85^{\star *}$ & $0.52 \pm 0.36^{*}$ \\
\hline le fragment & & $0.02 \pm 0.06$ & $0.11 \pm 0.15$ & $0.06 \pm 0.09$ & $0.15 \pm 0.30$ & $0.37 \pm 0.52$ & $0.40 \pm 0.31^{*}$ & $0.28 \pm 0.20$ \\
\hline Chromosome bridge & $0.02 \pm 0.05$ & $0.04 \pm 0.08$ & $0.02 \pm 0.06$ & $0.04 \pm 0.08$ & $0.09 \pm 0.24$ & $0.38 \pm 0.22^{\star *}$ & $0.02 \pm 0.06$ & $0.19 \pm 0.11^{\star \star}$ \\
\hline Total & $0.32 \pm 0.16$ & $1.35 \pm 0.98$ & $1.16 \pm 0.55$ & $2.04 \pm 0.95^{\star *}$ & $3.51 \pm 1.63^{* *}$ & $7.31 \pm 0.91^{\text {** }}$ & $2.95 \pm 1.02^{\star *}$ & $3.28 \pm 0.71^{\star \star}$ \\
\hline $\begin{array}{l}\text { MN } \\
\text { F }_{1} \text { cells }\end{array}$ & $0.13 \pm 0.09$ & $0.50 \pm 0.40$ & $0.75 \pm 0.41^{\star \star}$ & $1.01 \pm 0.32^{\star \star}$ & $1.37 \pm 0.34^{\star \star}$ & $2.71 \pm 0.73^{\star *}$ & $0.96 \pm 0.31^{\text {** }}$ & $0.52 \pm 0.28$ \\
\hline
\end{tabular}

${ }^{1}$ Negative control. ${ }^{*}$ Significant by Kruskal-Wallis test with a posteriori Student-Newman-Keuls test $\left({ }^{*} \mathrm{P}<0.05\right.$; ${ }^{* *} \mathrm{P}$ $<0.01$ ). MMS (methyl methanesulfonate: positive control). The results refer to analysis of 5000 cells per treatment. 
Table 2. Frequency of chromosome alterations in meristematic cells and of micronuclei (MN) in $\mathrm{F}_{1}$ cells of Allium cepa radicles after 24-h exposure to the aqueous leaf extract of Jatropha gossypiifolia.

\begin{tabular}{|c|c|c|c|c|c|c|c|c|}
\hline \multirow{2}{*}{ Chromosome alteration } & \multicolumn{8}{|c|}{ Frequency $(\%)$} \\
\hline & Distilled water ${ }^{1}$ & 0.001 & 0.01 & 0.1 & 1 & 10 & MMS3 $\left(4 \times 10^{-4} \mathrm{M}\right)$ & Trifluralin $(0.84 \mathrm{ppm})$ \\
\hline Chromosome adherence & $0.44 \pm 0.53$ & $1.20 \pm 0.56^{* 2}$ & $1.08 \pm 0.51^{*}$ & $1.17 \pm 0.54^{*}$ & $1.12 \pm 0.51$ & $1.60 \pm 0.97^{* \star}$ & $0.29 \pm 0.22$ & $2.35 \pm 1.62^{* *}$ \\
\hline C-metaphase & $0.04 \pm 0.12$ & $0.11 \pm 0.15$ & $0.22 \pm 0.30$ & $0.27 \pm 0.38$ & $0.28 \pm 0.34$ & $0.35 \pm 0.38^{*}$ & $0.18 \pm 0.17$ & $0.79 \pm 0.58^{* *}$ \\
\hline Chromosome loss & $0.10 \pm 0.10$ & $0.15 \pm 0.17$ & $0.18 \pm 0.12$ & $0.22 \pm 0.22$ & $0.14 \pm 0.21$ & $0.20 \pm 0.16$ & $0.04 \pm 0.08$ & $0.49 \pm 0.58$ \\
\hline Binucleated cell & $0.00 \pm 0.00$ & $0.04 \pm 0.12$ & $0.04 \pm 0.12$ & $0.16 \pm 0.40$ & $0.07 \pm 0.15$ & $0.09 \pm 0.16$ & $0.00 \pm 0.00$ & $0.92 \pm 1.25$ \\
\hline Polyploid cell & $0.00 \pm 0.00$ & $0.04 \pm 0.08$ & $0.00 \pm 0.00$ & $0.04 \pm 0.08$ & $0.00 \pm 0.00$ & $0.00 \pm 0.00$ & $0.00 \pm 0.00$ & $0.47 \pm 0.48$ \\
\hline Multipolar anaphase & $0.00 \pm 0.00$ & $0.00 \pm 0.00$ & $0.00 \pm 0.00$ & $0.00 \pm 0.00$ & $0.00 \pm 0.00$ & $0.02 \pm 0.06$ & $0.00 \pm 0.00$ & $0.30 \pm 0.45$ \\
\hline Lobulated nucleus & $0.00 \pm 0.00$ & $0.00 \pm 0.00$ & $0.00 \pm 0.00$ & $0.00 \pm 0.00$ & $0.00 \pm 0.00$ & $0.04 \pm 0.08$ & $0.00 \pm 0.00$ & $3.74 \pm 3.19^{* *}$ \\
\hline Nuclear bud & $0.08 \pm 0.10$ & $0.22 \pm 0.14$ & $0.24 \pm 0.31$ & $0.16 \pm 0.22$ & $0.58 \pm 0.47^{*}$ & $0.33 \pm 0.31^{*}$ & $0.24 \pm 0.23$ & $1.32 \pm 0.52^{\star *}$ \\
\hline Micronuclei & $0.20 \pm 0.19$ & $0.32 \pm 0.60$ & $0.66 \pm 0.51$ & $0.72 \pm 0.29$ & $0.81 \pm 0.57$ & $0.94 \pm 0.70^{*}$ & $3.54 \pm 2.30^{* *}$ & $1.71 \pm 1.09^{* *}$ \\
\hline Chromosome fragment & $0.02 \pm 0.06$ & $0.06 \pm 0.17$ & $0.07 \pm 0.13$ & $0.07 \pm 0.09$ & $0.10 \pm 0.15$ & $0.07 \pm 0.16$ & $0.44 \pm 0.38$ & $0.11 \pm 0.24$ \\
\hline Chromosome bridge & $0.00 \pm 0.00$ & $0.27 \pm 0.20^{* *}$ & $0.26 \pm 0.25^{* *}$ & $0.24 \pm 0.23^{* *}$ & $0.24 \pm 0.34$ & $0.24 \pm 0.23^{* *}$ & $0.22 \pm 0.19^{* *}$ & $0.47 \pm 0.58^{* *}$ \\
\hline Total & $0.88 \pm 0.79$ & $2.43 \pm 1.15$ & $2.75 \pm 0.82^{\star \star}$ & $3.05 \pm 0.95^{\star *}$ & $3.34 \pm 1.69^{* *}$ & $3.86 \pm 1.51^{\text {** }}$ & $4.95 \pm 2.20^{* *}$ & $12.67 \pm 6.32^{* *}$ \\
\hline MN F 1 cells & $0.62 \pm 0.46$ & $0.96 \pm 0.82$ & $1.32 \pm 0.74^{*}$ & $1.38 \pm 0.44^{*}$ & $1.47 \pm 0.48^{* \star}$ & $1.54 \pm 0.83^{* *}$ & $3.16 \pm 1.59^{* *}$ & $1.57 \pm 0.73^{* \star}$ \\
\hline
\end{tabular}

In separate analysis of CA, chromosome adherence was significant in $\mathrm{EE}(0.001,0.1$, and $1 \mathrm{mg} / \mathrm{mL})$ and $\mathrm{AE}(0.001,0.01,1$, and $10 \mathrm{mg} / \mathrm{mL})$, and the presence of C-metaphases was significant at 1 and $10 \mathrm{mg} / \mathrm{mL} \mathrm{EE}$ and $\mathrm{AE}$, respectively (Tables 1 and 2). Chromosome loss was significant only in 1 and $10 \mathrm{mg} / \mathrm{mL} \mathrm{EE}$, whereas nuclear buds were significant at 1 and $10 \mathrm{mg} / \mathrm{mL}$ of both the extracts. Multipolarity, polyploid metaphases, binucleated cells, and lobulated nuclei were detected at most of the concentrations in theboth extracts, but were not significant (Tables 1 and 2). Chromosome fragments and bridges (Tables 1 and 2) were also observed, but only bridges were significant in $10 \mathrm{mg} / \mathrm{mL} E E$ and $A E(0.001,0.01,1$, and $10 \mathrm{mg} / \mathrm{mL})$. Significant frequencies of MN were observed for $\operatorname{EE}(0.001,0.1,1$ and $10 \mathrm{mg} / \mathrm{mL})$ and $10 \mathrm{mg} / \mathrm{mL} \mathrm{AE}$.

Similar results were observed in case of $M N$ in the $F_{1}$ cells (Tables 1 and 2 ). The significant presence of $\mathrm{MN}$ in meristematic, as well as, in the $\mathrm{F}_{1}$ cells in both the extracts indicates a mutagenic effect at the chromosome level.

The phytochemical profile of EE revealed the presence of monoterpenes, diterpenes, triterpenes, sesquiterpenes, steroids, and flavonoids, whereas that of $\mathrm{AE}$ demonstrated flavonoids and saponins.

\section{DISCUSSION}

Overall, both extracts $\mathrm{AE}$ and $\mathrm{EE}$ showed cytotoxicity and genotoxicity for the higher tested concentrations $(0.1,1$, and $10 \mathrm{mg} / \mathrm{mL})$, whereas the concentrations 0.001 and $0.01 \mathrm{mg} / \mathrm{mL}$ displayed cytotoxicity only in case of $\mathrm{EE}$; only at a concentration of $0.01 \mathrm{mg} / \mathrm{mL}$ was $\mathrm{AE}$ genotoxic. On the other hand, a mutagenic effect at the chromosome level was observed at all concentrations of $E E$ (except $0.01 \mathrm{mg} / \mathrm{mL})$ and the highest concentration of $A E(10 \mathrm{mg} / \mathrm{mL})$.

The reduction in the $\mathrm{Ml}$ (cytotoxicity) of $A$. cepa treated with $\mathrm{EE}$ can be attributed to the different classes of terpenes observed in the present study, particularly diterpenes, which are some of the most toxic and cytotoxic compounds present in Jatropha (Devappa et al., 2011). The action of diterpenes on MI reduction may be due to a decrease in the (intracellular) calcium concentration, inhibiting the protein kinase C, and thus reducing cell proliferation (Paes et al., 2012; Sheremet et al., 2012). The flavonoids in EE may also be associated with these adverse effects on the cells. On the other hand, in AE the reduction in MI seems to have been caused by synergism of flavonoids and/or saponins, as observed in Myristica fragrans (Akinboro et al., 2011). Studies of cytotoxicity and inhibition of topoisomerase II have been previously reported for diterpenes, 
triterpenes, flavonoids, lignin (Zheng et al., 2010), and saponins (Sánchez-Burgos et al., 2013).

The probable inhibitory action on topoisomerase II by the phytochemicals of the extracts may have induced alterations in the condensation (chromosome adherence), and consequently the mitotic segregation (chromosome loss), as observed in A. cepa by Żabka et al. (2014). Chromosome adherence and $\mathrm{C}$-metaphases observed in the two extracts were the result of genotoxic effects, as they represent damage to the genetic material that was not necessarily fixed in the organism (Leme and Marin-Morales, 2009). The presence of these alterations confirms the interference of $J$. gossypiifolia phytochemicals with the spindle fibers, characteristic of aneugenic action.

Aneugenic activities may also generate other types of cell alterations, such as multipolar anaphases, lobulated nuclei, and polyploid cells, as a consequence of spindle fiber formation errors. Lobulated nuclei, for instance is resulted from multipolar divisions (Fernandes et al., 2009). However, these alterations were not significant in any of the evaluated extracts. This indicates that the $\mathrm{C}$-metaphases did not contribute to these alterations, suggesting that they dispose of a reversible mechanism (Odeigah et al., 1997).

Chromosome bridges, chromosome fragments, and part of the MN formation may be attributed to clastogenic activity (Fenech et al., 2011). However, the chromosome fragments were not significant at all the concentrations of the extracts. Bridges were significant for most of the $A E$ concentrations, but only at $10 \mathrm{mg} / \mathrm{mL}$ for EE. Therefore, the clastogenic action in AE seems to be the result of synergistic action of flavonoids and/or saponins because terpenes do not seem to have this type of action. EE showed significant number of chromosome bridges only at concentration 10 $\mathrm{mg} / \mathrm{mL}$, possibly resulting from the action of high concentrations of flavonoids (in the absence of saponins) or terpenes.

In EE, the non-significant formation of chromosome fragments (at all concentrations) and chromosome bridges (at the four lower concentrations) indicate that the MN (also representing the mutagenic effect) observed in the case of various EE concentrations possibly did not originate from chromosome fragments, but rather from an aneugenic action involving one or more complete chromosomes not incorporated into the main nucleus during the cell cycle (Fenech et al., 2011), or else from the nuclear buds (Fernandes et al., 2009). This proposition reinforces the association of terpenes and/or flavonoids (in the absence of saponins) to the aneugenic, but not clastogenic potential. Thus, in EE aneugenicity seems to be the main activity, probably arising from the action of terpenes and/or flavonoids (in the absence of saponins). On the other hand, in AE, the clastogenic action seems to be the main activity resulting in the negative effects on the cells of $A$. cepa, probably as a consequence of the synergetic action of flavonoids and/or saponins.

The obtained results also showed significant frequency of $M N$ in the $F_{1}$ cells in both extracts at concentrations $0.01 \mathrm{mg} / \mathrm{mL}$ and above. The $\mathrm{MN}$ in the $\mathrm{F}_{1}$ cells may have originated from unrepaired or incompletely repaired damaged-DNA of parental cells (Ribeiro, 2003), indicating a mutagenic activity at the chromosome level, which was probably numerical. The presence of fragments was not significant in any of the two treatments.

Although, J. gossypiifolia is considered an important plant with potential for the generation of pharmacological and/or biotechnological products (Félix-Silva et al., 2014), the assays performed in this study indicated cytotoxicity, genotoxicity, and/or mutagenicity at the chromosome level for all the tested concentrations of the ethanolic leaf extract and for the concentrations $0.01 \mathrm{mg} / \mathrm{mL}$ or above, of the aqueous leaf extract of $J$. gossypiifolia, particularly for the three highest concentrations. This alerts us to the eventual possibility of $J$. gossypiifolia leaf extracts posing risk to human health, even though they possess various medicinal applications. Therefore, complementary studies 
are necessary for determination, isolation, and analysis of the plant's bioactive compounds and identification of those that are potentially interesting from the therapeutic point of view and do not cause adverse effects to health.

\section{Conflicts of Interest}

The authors declare no conflicts of interest.

\section{ACKNOWLEDGMENTS}

We would like to thank Dr. Francisco Soares Filho for taxonomic identification of the botanic material (J. gossypiifolia) and the Agronomic Institute of Pernambuco for the seeds of $A$. cepa cv. Vale Ouro IPA - 11. This work was funded by the Programa de Fomento à Pós-Graduação (PROF) from the Coordenação de Aperfeiçoamento de Pessoal de Nível Superior (CAPES/Brazil).

\section{REFERENCES}

Akinboro A, Mohamed KB, Asmawi MZ, Sulaiman SF, et al. (2011). Antioxidants in aqueous extract of Myristica fragrans (Houtt.) suppress mitosis and cyclophosphamide-induced chromosomal aberrations in Allium cepa L. cells. J. Zhejiang Univ. Sci. B. 12: 915-922. http://dx.doi.org/10.1631/jzus.B1000315

Ayres M, Ayres JM, Ayres DL, Santos AS, et al. (2007). BioEstat 5.3: Aplicações estatísticas nas áreas das ciências biomédicas. Belém: Sociedade Civil Mamirauá.

Bagatini DM, Silva ACF and Tedesco SB (2007). Uso do sistema teste de Allium cepa como bioindicador de genotoxicidade de infusões de plantas medicinais. Rev. Bras. Farmacogn. 17: 444-447. http://dx.doi.org/10.1590/S0102$\underline{695 X 2007000300019}$

Devappa RK, Makkar HPS, Becker K (2011). Jatropha diterpenes: a review. J. Am. Oil Chem. Soc. 88: 301-322. http://dx.doi. org/10.1007/s11746-010-1720-9

Félix-Silva J, Giordani RB, Silva-Jr AA, Zucolotto SM, et al. (2014). Jatropha gossypiifolia L. (Euphorbiaceae): A review of traditional uses, phytochemistry, pharmacology, and toxicology of this medicinal plant. Evid. Based Complement Alternat. Med. Doi: http://dx.doi.org/10.1155/2014/369204.

Fenech M, Kirsch-Volders M, Natarajan AT, Surralles J, et al. (2011). Molecular mechanisms of micronucleus, nucleoplasmic bridge and nuclear bud formation in mammalian and human cells. Mutagenesis 26: 125-132. http://dx.doi.org/10.1093/ mutage/geq052

Fernandes TC, Mazzeo DE and Marin-Morales MA (2009). Origin of nuclear and chromosomal alterations derived from the action of an aneugenic agent-Trifluralin herbicide. Ecotoxicol. Environ. Saf. 72: 1680-1686. http://dx.doi.org/10.1016/j. ecoenv.2009.03.014

<edb>Kawanga V (2007). Jatropha gossypiifolia L. In: Schmelzer, G.H. \& Gurib-Fakim, A. (Editors). Prota 11(1): Medicinal plants/Plantes médicinales 1. [CD-Rom]. PROTA, Wageningen, Netherlands.</edb>

Leme DM and Marin-Morales MA (2009). Allium cepa test in environmental monitoring: A review on its application. Mutat. Res. 682: 71-81. http://dx.doi.org/10.1016/j.mrrev.2009.06.002

Ma TH, Xu Z, Xu C, McConnell H, et al. (1995). The improved Allium/Vicia root tip micronucleus assay for clastogenicity of environmental pollutants. Mutat. Res. 334: 185-195. http://dx.doi.org/10.1016/0165-1161(95)90010-1

Mariz SR, Borges ACR, Melo-Diniz MFF, Medeiros IA (2010). Possibilidades terapêuticas e risco toxicológico de Jatropha gossypiifolia L.: uma revisão narrativa. Rev. Bras. Pl. Med. 12: 346-357. http://dx.doi.org/10.1590/S1516$\underline{05722010000300013}$

Odeigah PGC, Nurudeen O, Amund OO (1997). Genotoxicity of oil field wastewater in Nigeria. Hereditas 126: 161-167. http:// dx.doi.org/10.1111/j.1601-5223.1997.00161.x

Oliveira FCS, Barros RFM, Moita Neto JM (2010). Plantas medicinais utilizadas em comunidades rurais de Oeiras, semiárido piauiense. Rev. Bras. Pl. Med. 12: 282-301. http://dx.doi.org/10.1590/S1516-05722010000300006

Paes AMA, Camara AL, Freire SMF and Borges MOR (2012). Relaxant effect of Jatropha gossypiifolia L. on uterine smooth muscle. Int. J. Phytomed. 4: 310-313. 
Randau KP, Florêncio DC, Ferreira CP and Xavier HS (2004). Pharmacognostic study of Croton rhamnifolius H.B.K. and Croton rhamnifolioides Pax \& Hoffm. (Euphor- biaceae). Rev. Bras. Farmacogn. 14: 89-96. http://dx.doi.org/10.1590/ S0102-695X2004000200001

$<$ edb>Ribeiro LR (2003). Mutagênese ambiental. In: teste do micronúcleo em medula óssea de roedores in vivo, Canoas, Ulbra, 201-219.</edb>

Sabandar CW, Ahmat N, Jaafar FM and Sahidin I (2013). Medicinal property, phytochemistry and pharmacology of several Jatropha species (Euphorbiaceae): A review. Phytochemistry 85: 7-29. http://dx.doi.org/10.1016/j.phytochem.2012.10.009

Sánchez-Burgos JA, Ramirez-Mares MV, Larrosa MM, Gallegos-Infante JA, et al. (2013). Antioxidant, antimicrobial, antitopoisomerase and gastroprotective effect of herbal infusions from four Quercus species. Ind. Crop Prod. 42: 57-62. http://dx.doi.org/10.1016/j.indcrop.2012.05.017

Sheremet laA, Emets Al, Azmi A, Vissenberg K, et al. (2012) Effect of inhibitors serine/threonine protein kinases and protein phosphatases on mitosis progression of synchronized tobacco by-2 culture. Tsitol. Genet. 46: 3-11.

Silva FAS and Azevedo CAV (2002). Versão do programa computacional Assistat para o sistema operacional Windows. Rev. Bras. Prod. Agroind. 4: 71-78.

Singh P and Singh A (2012). Acute toxic effects of medicinal plant Jatropha gossypifolia on non- target fish and mice. J. Agr. Res. 1: 433-438.

Żabka A, Polit JT, Bernasinska J and Maszewski J (2014). DNA topoisomerase II-dependent control of the cell cycle progression in root meristems of Allium cepa. Cell Biol. Int. 38: 355-367. http://dx.doi.org/10.1002/cbin.10211

Zheng MS, Lee YK, Li Y, Hwangbo K, et al. (2010). Inhibition of DNA topoisomerases I and II and cytotoxicity of compounds from Ulmus davidiana var. japonica. Arch. Pharm. Res. 33: 1307-1315. http://dx.doi.org/10.1007/s12272-010-0903-0 